\title{
Unexpected long-term population dynamics in a canopy-forming gorgonian coral following mass mortality
}

\author{
Roberta Cupido ${ }^{1,2, *}$, Silvia Cocito ${ }^{1}$, Mattia Barsanti ${ }^{1}$, Sergio Sgorbini ${ }^{1}$, \\ Andrea Peirano ${ }^{1}$, Giovanni Santangelo ${ }^{2}$ \\ ${ }^{1}$ Italian National Agency for New Technologies, Energy and Sustainable Economic Development (ENEA), \\ Marine Environment Research Centre, PO Box 224, 19100 La Spezia, Italy \\ ${ }^{2}$ Department of Biology (Zoology), University of Pisa, via A. Volta 6, 56126 Pisa, Italy
}

\begin{abstract}
Gorgonian corals are long-lived, slow-growing species exhibiting slow population dynamics. Demographic data collected over a period of $11 \mathrm{yr}$ on a small population of temperate, canopyforming gorgonians dwelling near the edge of the summer thermocline in the northwestern Mediterranean Sea enabled us to assess its responses to the large mortality events that occurred in 1999 and 2003. Changes in population density, size structure and recruitment were examined. Overall, 2101 adult colonies and recruits were observed in situ and 240 photographic plots analyzed. During the first 3 years (2004 to 2006) after the mass mortalities, our measurements revealed a dramatic reduction in the density of healthy colonies $(90 \%$ suffered total or partial mortality), a shift in the dominant size class towards smaller size and a significant reduction in recruitment. In the following years 2007 to 2008) a significant recovery of injured colonies was found, with almost complete detachment of the dead colonies, a reduction in mortality and a 4 -fold increase in recruitment. These findings indicate clear-cut restoration trends of the population, suggesting that recovery after extensive mortality could be faster than predicted by our current knowledge of gorgonian population dynamics.
\end{abstract}

KEY WORDS: Octocorals $\cdot$ Paramuricea clavata $\cdot$ Mass mortality $\cdot$ Recruitment $\cdot$ Sediment cover $\cdot$ Population dynamics $\cdot$ Eastern Ligurian Sea $\cdot$ Global climate change

\section{INTRODUCTION}

In the last few years marine ecologists increasingly have had to contend with mass mortality events affecting different subtidal communities and populations. Recently, some meaningful examples have been encountered in Mediterranean benthic populations living at the summer thermocline edge. In 1999 and 2003, 2 episodes of mass mortality, co-occurring with anomalous warming of the water column, affected several populations of benthic suspension feeders in the northwestern Mediterranean (Cerrano et al. 2000, Bramanti et al. 2005, Linares et al. 2005, Cupido et al. 2008). In particular, in France and Italy populations of the temperate purple sea fan Paramuricea clavata (Risso
1826), one of the main components of the Mediterranean coralligenous assemblages of circalittoral rocky bottoms (Ballesteros 2006), were damaged or killed in a proportion ranging from 60 to $90 \%$ (Linares et al. 2005, Cupido et al. 2008). In one case, P. clavata mortality was associated with a pathogenic, thermaldependent bacterium Vibrio coralliilycticus (Bally \& Garrabou 2007),

Gorgonians are long-lived species (their lifespan may exceed a full century; Roark et al. 2006) that play a paramount role in shaping benthic communities by increasing local biodiversity and promoting nursery effects (Gili \& Coma 1998). Large gorgonians such as Paramuricea clavata form dense patches (up to 59 colonies $\mathrm{m}^{-2}$; Linares et al. 2005) with large fans (up to 
$1 \mathrm{~m}$ high) that resemble the tangled twigs of trees in a miniature forest. They provide shelter to a diversified assemblage of animals and algae and reduce water flow in their surroundings (Gili \& Coma 1998), thereby stabilizing understorey habitats. Large gorgonians may therefore be defined as 'canopy-forming species' since, like erect algae, they affect sediment deposition and may in turn be affected by sedimentation in many ways due to their morphological and physiological features (Airoldi 2003, Connell 2003). In many coastal areas, the decline of canopy-forming species is regarded as a major threat to the overall biodiversity of marine benthic communities (Bulleri et al. 2002).

The population of Paramuricea clavata living in the Gulf of La Spezia (Ligurian Sea, Italy), an area with high sedimentation and turbidity, provides a paradigmatic example of the responses of a small population dwelling near the thermocline edge to the mortality associated with anomalous temperature increases. In 1999 and 2003, 2 large mortalities affected $90 \%$ of the overall population (Cupido et al. 2008). The availability of pre-event data (1998) on population density, size structure, recruitment and total and partial mortality enabled description of the population trends over a period of $11 \mathrm{yr}$. A demographic approach, based on single populations, proved to be highly fruitful for fostering populations and promoting species conservation (Beissinger \& McCullough 2002). By following such an approach, researchers can project population trends over time by using suitable demographic models and comparing the findings with the real dynamics of the population (Caswell 2001, Santangelo et al. 2007). In the present study, rather unexpected changes in both population dynamics and sediment cover are described and discussed.

\section{MATERIALS AND METHODS}

Study area. The present study was carried out on the Paramuricea clavata population living on a vertical, coralligenous reef on the western cliffs of Tinetto Island and Tinetto Shoal, La Spezia Gulf, Ligurian Sea, Italy $\left(44^{\circ} 01^{\prime} \mathrm{N}, 09^{\circ} 50^{\prime} \mathrm{E}\right)$. The upper bathymetric limit (largely influenced by temperature and water turbidity, as per Ballesteros 2006) is, at $17 \mathrm{~m}$, quite close to the summer thermocline, while the lower bathymetric limit is $25 \mathrm{~m}$, where the cliff ends on a flat, muddy bottom. Between 20 and 23 m, P. clavata forms a canopy of some $1000 \mathrm{~m}^{2}$ (Cupido et al. 2008). In late-summer 1999 and 2003, temperatures peaked at $24^{\circ} \mathrm{C}, 2$ to $3^{\circ} \mathrm{C}$ higher than in 1992 to 1998 (ENEA Center data cited in Cerrano et al. 2000).

The area is characterized by high turbidity due to the terrestrial runoff from the Magra River and sewage from the city of La Spezia, both of which get caught up in the westward Ligurian current (Astraldi \& Gasparini 1986). The medium stream speed is $15 \mathrm{~cm} \mathrm{~s}^{-1}$ and the maximum is $90 \mathrm{~cm} \mathrm{~s}^{-1}$ (Cocito et al. 1997). The highest water transparency values were found in April and July (at 8 and $10.5 \mathrm{~m}$, respectively) and the lowest in October and December (4.5 $\mathrm{m}$ in both). Deposited sediment composition was constant over the year (silt $80 \%$; clay $15 \%$ and very fine sand $5 \%$; $\theta 3.9$ to $5.5 \mu \mathrm{m})$. Total suspended solids ranges between 1.61 and $2.65 \mathrm{mg} \mathrm{l}^{-1}$

Long-term monitoring. The population was monitored by SCUBA diving following 2 different approaches: a statistical one, based on random replicated plots, and a demographic one, based on permanent plots. Due to the small size of this population, which had been stricken by mass mortality, only nondestructive sampling was applied. During the study period, a total of 1599 observations were made in situ on adult colonies in random plots; 279 and 223 observations were made (in 2007 and in 2008, respectively) within fixed plots.

To evaluate spatial and temporal variations in population structure, 6 random plots of $1 \mathrm{~m}^{2}$ were sampled in each location in 1998, and then yearly from 2004 to 2008 (after the 2 mortality events). Data from the 2 locations did not differ statistically and, consequently, were pooled.

The percentage of colony surface injured was estimated in situ. Colony height was measured with a ruler, and both undamaged and partially damaged colonies were grouped into 6 height classes $(<5,6-15$, $16-25,26-35,36-45$, and $>46 \mathrm{~cm})$; colonies of $<5 \mathrm{~cm}$ height were considered to be recruits (Cerrano et al. 2005). Henceforth, colonies of $>5 \mathrm{~cm}$ height are therefore referred to as adult colonies. Pre- and post-mortality numbers of adult and dead colonies and recruitment density were checked by 1-way ANOVA. Differences between years were checked via a Student-Newman-Keuls (SNK) test, and the overall population growth was expressed in terms of the discrete population growth rate $(\lambda)$ summarizing mortality and recruitment in the different years. Variations in extent of injury were checked by 1-way ANOVA.

To evaluate net recruitment rates (recruitment mortality in a given year), 6 permanent plots of $1 \mathrm{~m}^{2}$ were sampled yearly at each location. All colonies, recruits included, were mapped to enable re-identification during the surveys that followed.

Percentage canopy cover was monitored by means of photographic sampling from 1998 to 2007, using a Nikonos V camera (Nikon) with a wide-angle lens. Photographs covered a $1 \mathrm{~m}^{2}$ area delimited by a metal frame. Canopy disappearance affects sediment dynamics (Airoldi 2003), so we examined percentage 
sediment cover as well. This photographic sampling was performed with a $35 \mathrm{~mm}$ lens covering $600 \mathrm{~cm}^{2}$. In each location, 12 photographs were taken randomly each year, for both Paramuricea clavata and sediment cover, for a total of 240 photographs. Scanned slides were processed with Coral Point Count with Excel extension (CPCe) software (National Coral Reef Institute, www.nova.edu/ncri/research/a10.html). $P$. clavata and sediment cover \% were measured by contouring colony area and sediment patches in each slide. The data was analyzed by 1-way ANOVA. Differences between samplings were checked with the SNK test. All variances, checked via Levene's test, were homogeneous.

\section{RESULTS}

Between 1998 and 2006, the population structure, examined on random plots, changed dramatically in terms of both size structure and density (Figs. 1a,b \& $2 \mathrm{a}, \mathrm{b}$ ): adult colony density decreased by $78.3 \%$ (from $33.7 \pm 3.2$ in 1998 to $7.3 \pm 1.2$ and $5.1 \pm 1.1$ colonies $^{-2}$ in 2004 and 2006, respectively) (Fig. 2a), and the dominant class shifted towards smaller colonies (16 to $25 \mathrm{~cm}$ in height in 1998 and 6 to 15 in 2004-2006) (Fig. 1a). Although adult colony density increased significantly over the next $2 \mathrm{yr}\left(11.2 \pm 1.6\right.$ colonies $\mathrm{m}^{-2}$ in 2007 and $11.3 \pm 1.3$ colonies $\mathrm{m}^{-2}$ in 2008) (1-way ANOVA, $F=28.674, \mathrm{p}<0.0001$; SNK test $1998>2007$ $=2008>2004=2005=2006, p<0.05)$, only $33 \%$ of the 1998 density was reached, and the original population size structure was far from being re-established (Fig. 2a).

Overall, 176 recruits were added to the population during the $5 \mathrm{yr}$ following the 1999 and 2003 mortality events. During the same period, recruit density decreased from $2.6 \pm 0.5$ in 1998 to around $0.8 \pm 0.3$ recruits $\mathrm{m}^{-2}$ between 2004 and 2006 and increased to
$5.8 \pm 1.2$ and $6.1 \pm 2.5$ recruits $\mathrm{m}^{-2}$ in 2007 and 2008, respectively (Fig. 2b), significantly exceeding the 1998 pre-event values (1-way ANOVA, $F=3.45, \mathrm{p}<0.05$; SNK test, $\mathrm{p}<0.05)$. In 2007 and 2008 recruitment density exhibited high variability amongst plots, ranging from 0 to 33 recruits $\mathrm{m}^{-2}$ (Fig. 2b).

$\lambda$ revealed decreasing trends during the period of 2004 to $2006(0.23,0.78,0.92$ respectively), a large increase in 2007 (2.86) and near stable values (1.02) in 2008. The average net recruitment measured in 2008 on fixed plots was $0.2 \pm 1.8$ and $1.3 \pm 3.8$ at Tinetto Island and Tinetto Shoal, respectively. Thus, although some heavily damaged colonies were still dying, the population showed somewhat positive net recruitment rates. The mean annual mortality of recruits was $22.4 \%$ in both 2007 and 2008. The total injured surface showed a drastic, highly significant reduction from $57 \%$ in 2004 to $10 \%$ in 2008 (1-way ANOVA, $F=46.57, \mathrm{p}<0.0001$ ) (Fig. 2c). Dead colonies (which remained on the cliff for a long while) reached a density of about 21 colonies $\mathrm{m}^{-2}$ in 2004 and 2005 (Fig. 2d), corresponding to a mortality of $71.6 \%$, slightly lower than the calculated population mortality based on 2004 adult-colony density data $(78.3 \%)$. Stochastic sampling variability aside, this difference could be due to detachment of some dead colonies just before the 2004 sampling. Due to detachment, the number of dead colonies decreased in the years subsequent 2003 by $74 \%$ in 2007 and by a further $19 \%$ in 2008 (Fig. 2d). Paramuricea clavata $\%$ canopy cover decreased significantly between 1998 and 2008 (1-way ANOVA, $F=7.0437, \mathrm{p}<$ 0.0001; SNK test, $\mathrm{p}<0.05)$, remaining statistically constant between 2004 and 2006 (Fig. 2e). Percentage sediment cover increased significantly between 1998 and 2004 (1-way ANOVA, $F=14.247, \mathrm{p}<$ $0.0001)$, though it did not change statistically over subsequent years (Fig. 2f) (SNK test, $\mathrm{p}<0.0001,1998$ $>2004=2005=2006=2007$ ) .
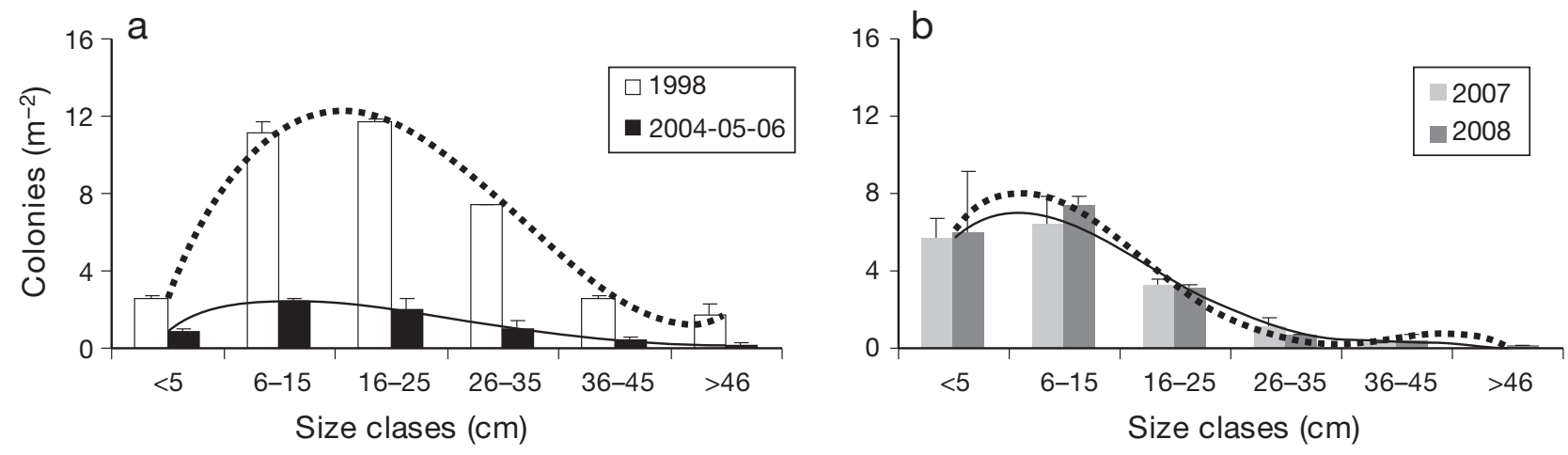

Fig. 1. Paramuricea clavata. Size structure of the population (living colonies) in the periods: (a) 1998 (—) and $2004-2006$ (*-.-) (b) 2007 (- 

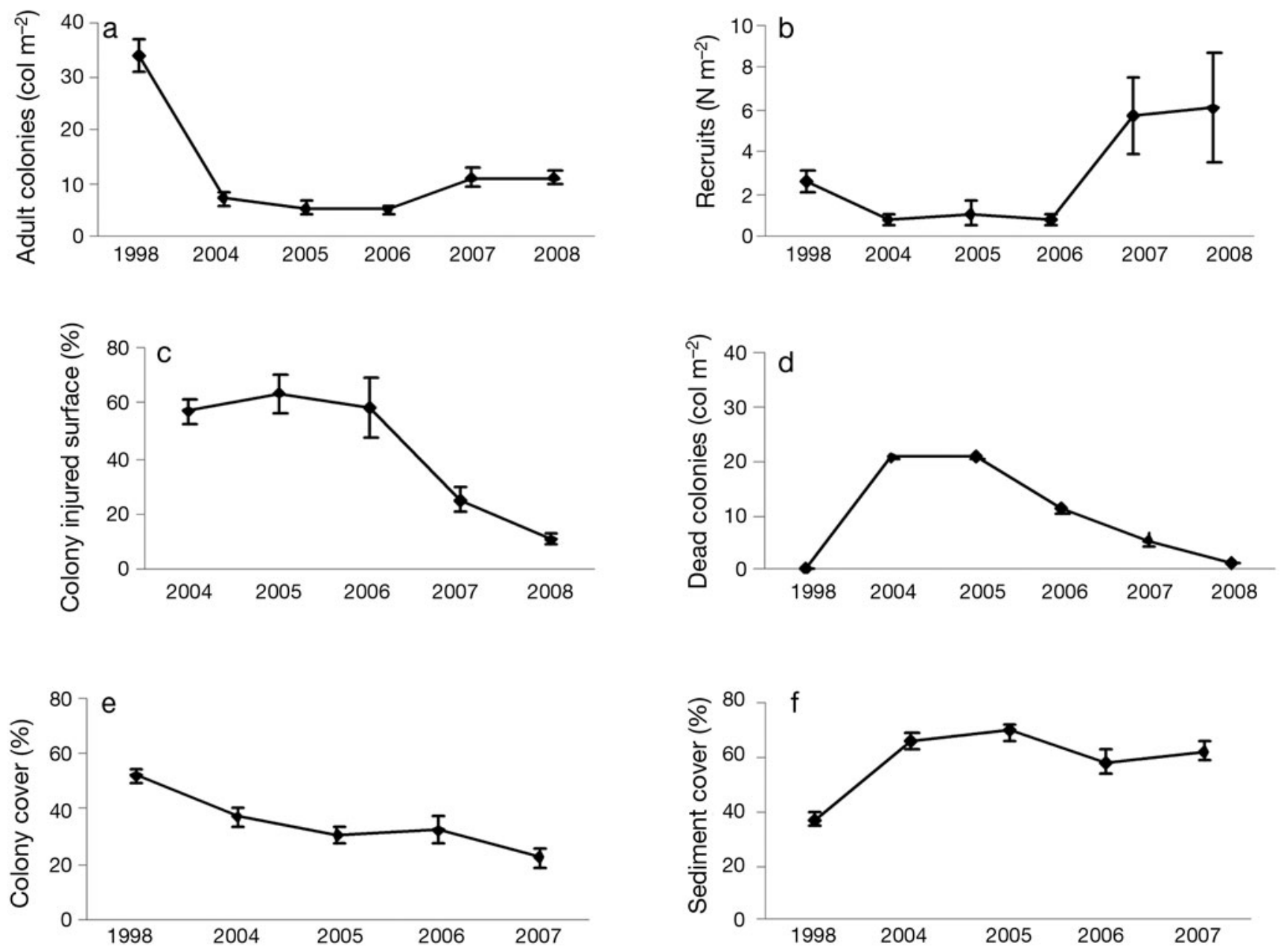

Fig. 2. Paramuricea clavata. Population trends over the 1998-2008 period: (a) adult colony density; (b) recruit density; (c) \% colony injured surface; (d) dead colony density. Trends of (e) \% living colony canopy cover and (f) \% sediment cover over 1998-2007. Values represent means from 2 locations $( \pm$ SE)

\section{DISCUSSION}

A Paramuricea clavata population dwelling near the edge of the summer thermocline in the northwestern Mediterranean was subjected to large mortality events associated with abnormal temperature increases occurring in late-summer 1999 and 2003. Consequently, colony density was reduced to $20 \%$, and recruitment to $25 \%$, of the pre-mortality values. Mortality affected all size classes but, because larger colonies were more heavily affected than others (Cupido et al. 2008), the population size-structure was altered, and the modal class shifted towards a smaller size.

The small size and geographic isolation of this population (the nearest upstream Paramuricea clavata population dwells at $50 \mathrm{n}$ miles south) suggested it should be subject to a high risk of extinction (Cupido et al. 2008). Moreover, this area is characterized by a high sedimentation load (deposited sediment on the vertical cliff ranged from $188 \pm 40 \mathrm{~g} \mathrm{~m}^{-2}$ to $375 \pm 61 \mathrm{~g} \mathrm{~m}^{-2}$; Cocito \& Cupido unpubl. data), which may reduce both survival and recruitment. Finally, silt sediment, considered an important source of stress for benthic suspension feeders (Babcock \& Davies 1991, Connell 2003), is predominant in the study area. However, in 2007 and 2008 the density of healthy adult colonies significantly increased, and recruitment peaked to up to double the pre-mortality values. Such values are about $5 \times$ higher than previously reported (Linares et al. 2005). Recruitment increased only after massive, delayed detachment of dead colonies, a fact that could be due to the increased availability of free space (a kind of competition between 'the living and the dead') (Fig. 3c), as reportedly occurring in dense terrestrial forests after fires (Terborgh et al. 2008). The dead colony canopy could also act as a mechanical filter for planulae, fos- 
tering the observed larval settlement on dead gorgonians rather than on the substratum. Such settlers are inevitably lost with dead colony detachment.

Since fecundity is strictly correlated to colony size (Coma et al. 1995), the loss of larger, highly reproductive colonies could greatly reduce the population reproductive output. Conversely, as the injured surface area of damaged colonies in the post-mortality period fell from 56 to $10 \%$ (the latter value is similar to healthy populations; Linares et al. 2009), reproductive output might have been increased due to the larger numbers of restored colonies in the population in 2007 and 2008.

Paramuricea clavata recruitment did not seem to be negatively affected by increases in sediment cover (Fig. 3d). In contrast to reports on reef corals whose reproduction and recruitment seem to be inhibited by high sedimentation load (Fabricius 2005), sediment may actually represent an additional food source for large resuspension feeders such as P. clavata (Rosenfeld et al. 1999), which have been defined as the 'ultimate consumer of seston' (Coma et al. 2001). Moreover, due to polyp rejection activity, P. clavata colonies could act as a living filter, reducing sediment on the vertical wall. This hypothesis could explain the significant increase in deposited sediment cover after the death of the $P$. clavata canopy.

Whatever the reasons, the studied population exhibited quite unexpected trends towards recovery. Paramuricea clavata is generally regarded as a low turnover, low recruitment species (Coma et al. 1995, 2004), and yet the population described here seems to show rather rapid dynamics, much more rapid than would be expected. Moreover, the average mortality of recruits $(22.37 \%)$, which is generally quite high in gor-

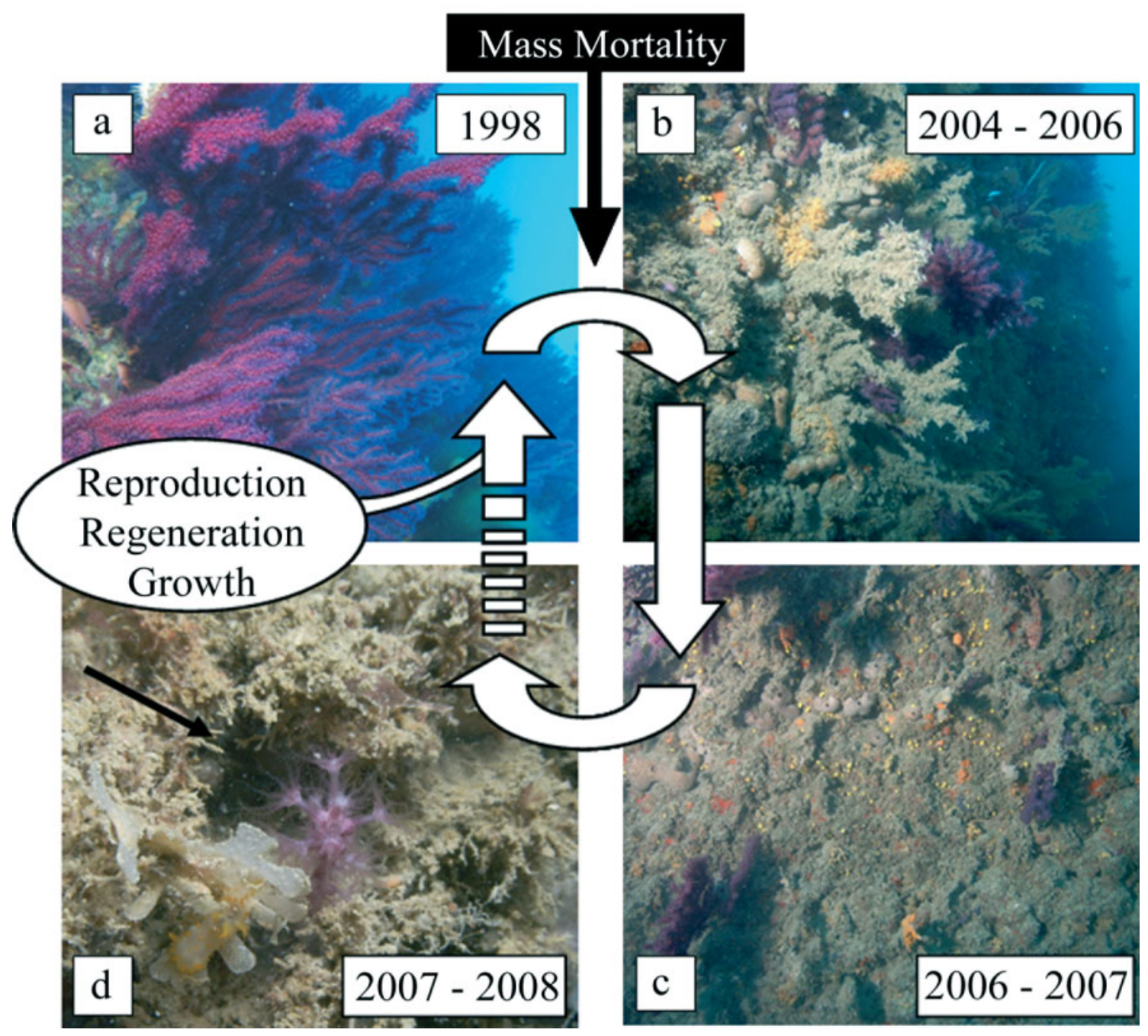

Fig. 3. Paramuricea clavata. Hypothetical population cycle: (a) healthy, crowded population (before 2003); (b) the stricken population (2004-2006); (c) population after dead colony detachment in 2006-2007; (d) increase in recruit density (2007, 2008). Black arrow in (d) indicates a recruit rising out of the sediment 
gonians, is lower than that reported for other $P$. clavata populations (27\%; (Linares et al. 2007).

Based on the available long-term data set (1998 to 2008) on this population, we have hypothesized cyclic dynamics (as schematized in Fig. 3), by which clear-cut population recovery and canopy reestablishment could start some years after a high-mortality event. Given such positive net-recruitment and population growth rates, the population could recover its original density in some years, though re-establishing the original size structure would take longer (assuming that additional large mortality events do not befall the population again).

Acknowledgements. We thank A. Cafazzo for revision of the English text.

\section{LITERATURE CITED}

Airoldi L (2003) The effects of sedimentation on rocky coastal assemblages. Oceanogr Mar Biol Annu Rev 41:161-203

Astraldi M, Gasparini GP (1986) La circolazione costiera nel Mar Ligure Orientale. Boll Mus Ist Biol Univ Genova 52: 317-331

Babcock R, Davies P (1991) Effects of sedimentation on settlement of Acropora millepora. Coral Reefs 9:205-208

Ballesteros E (2006) Mediterranean coralligenous assemblages: a synthesis of present knowledge. Oceanogr Mar Biol Annu Rev 44:123-195

Bally M, Garrabou J (2007) Thermodependent bacterial pathogens and mass mortalities in temperate benthic communities: a new case of emerging disease linked to climate change. Glob Change Biol 13:2078-2088

Beissinger SR, McCullough DR (2002) Population viability analysis. The University of Chicago Press, Chicago, IL

Bramanti L, Magagnini G, De Maio L, Santangelo G (2005) Recruitment, early survival and growth of the Mediterranean red coral Corallium rubrum (L 1758), a 4-year study. J Exp Mar Biol Ecol 314:69-78

Bulleri F, Benedetti-Cecchi L, Acunto S, Cinelli F, Hawkins SJ (2002) The influence of canopy algae on vertical patterns of distribution of low-shore assemblages on rocky coasts in the northwest Mediterranean. J Exp Mar Biol Ecol 267: 89-106

Caswell H (2001) Matrix population models: construction, analysis and interpretation, 2nd edn. Sinauer Associates, Sunderland, MA

> Cerrano C, Bavestrello G, Bianchi CN, Cattaneo-Vietti R and others (2000) A catastrophic mass-mortality episode of gorgonians and other organisms in the Ligurian Sea (north-western Mediterranean), summer 1999. Ecol Lett 3: 284-293

Editorial responsibility: Laura Airoldi, Ravenna, Italy
Cerrano C, Arillo A, Azzini F, Calcinai B and others (2005) Gorgonian population recovery after a mass mortality event. Aquat Conserv: Mar Freshw Ecosyst 15:147-157

Cocito S, Sgorbini S, Bianchi CN (1997) Zonation of a suspension-feeder assemblage on a temperate rocky shoal: the influence of water current and bottom topography. In: Hawkins LE, Hutchinson S, Jenson AC, Sheader M, Williams JA (eds) The responses of marine organisms to their environments. Proc 30th European Mar Biol Symp Univ Southampton. University of Southampton, p 183-192

Coma R, Zabala M, Gili JM (1995) Sexual reproductive effort in the Mediterranean gorgonian Paramuricea clavata. Mar Ecol Prog Ser 117:185-192

Coma R, Ribes M, Gili JM, Hughes RN (2001) The ultimate opportunists: consumers of seston. Mar Ecol Prog Ser 219: 305-308

Coma R, Pola E, Ribes M, Zabala M (2004) Long-term assessment of temperate octocoral mortality patterns, protected vs. unprotected areas. Ecol Appl 14:1466-1478

Connell SD (2003) The monopolization of understorey habitat by subtidal encrusting coralline algae: a test of the combined affects of canopy-mediated light and sedimentation. Mar Biol 142:1065-1071

Cupido R, Cocito S, Sgorbini S, Bordone A, Santangelo G (2008) Response of a gorgonian (Paramuricea clavata) population to mortality events: recovery or loss? Aquat Conserv: Mar Freshw Ecosyst 18:984-992

Fabricius KE (2005) Effects of terrestrial runoff on the ecology of corals and coral reefs: review and synthesis. Mar Pollut Bull 50:125-146

Gili JM, Coma R (1998) Benthic suspension feeders: their paramount role in littoral marine food webs. Trends Ecol Evol 13:316-321

Linares C, Coma R, Diaz D, Zabala M, Hereu B, Dantart L (2005) Immediate and delayed effects of a mass mortality event on gorgonian population dynamics and benthic community structure in the NW Mediterranean Sea. Mar Ecol Prog Ser 305:127-137

Linares C, Coma R, Garrabou J, Bianchimani O, Drap P, Serrano E, Zabala M (2009) Contribution to the conservation of coralligenous communities through studies on population ecology of Mediterranean gorgonians. Proceedings of the 1st Mediterranean Symposium on the conservation of the coralligenous and other calcareous bio-concretions, Tabarka, Tunisia, p 106-111

> Roark EB, Guilderson TP, Dunbar RB, Ingram L (2006) Radiocarbon-based ages and growth rates of Hawaiian deepsea corals. Mar Ecol Prog Ser 327:1-14

Rosenfeld M, Bresler V, Abelson A (1999) Sediment a possible source of food for corals. Ecol Lett 2:345-348

> Santangelo G, Bramanti L, Iannelli M (2007) Population dynamics and conservation biology of the over-exploited Mediterranean Red coral. J Theor Biol 244:416-423

- Terborgh J, Nunez-Iturri G, Pitman NCA, Valverde FHC and others (2008) Tree recruitment in an empty forest. Ecology 89:1757-1768

Submitted: April 3, 2009; Accepted: August 7, 2009

Proofs received from author(s): October 22, 2009 